Short Communication

\title{
A SURVEY OF HELMINTH INFECTIONS IN THE BLACK RAT FROM STARA ZAGORA DISTRICT, BULGARIA
}

\author{
Petar T. Iliev ${ }^{1}$ Georgi Zh. Georgiev' ${ }^{1}$ Zvezdelina T. Kirkova ${ }^{1}$, Borislava G. Chakarova² \\ ${ }^{1}$ Department of Veterinary Microbiology, Infectious and Parasitic Diseases, \\ Faculty of Veterinary Medicine, Trakia University, 6000 Stara Zagora, Bulgaria \\ ${ }^{2}$ Department of Hygiene, Epidemiology, Infectious and Parasitic Diseases, \\ Faculty of Medicine, Trakia University, 6000 Stara Zagora, Bulgaria
}

Received 6 February 2017; Received in revised form 9 May 2017; Accepted 5 June 2017

\begin{abstract}
A field study was conducted to disclose the prevalence of different helminth parasites in the black rat, Rattus rattus, in some regions of Stara Zagora district, Bulgaria. Out of 67 examined rats, 53 (79.1\%) were found to be positive. Helminths of three classes were detected such as Cestoda: Hymenolepis diminuta (47.8\%), Hymenolepis nana (43.3\%), Taenia taeniaeformis larvae (7.5\%), Taenia polyacantha larvae (1.5\%); Secernentea: Syphacia obvelata (4.5\%), Aspiculuris tetraptera $(3.0 \%)$ and Adenophorea: Capillaria hepatica (9.0\%), Trichuris muris (3.0\%). Of all the investigated rats, 27 (40.3\%) were infected by one helminth species and $26(38.8 \%)$ by more than one. Hymenolepis diminuta was a predominant species in cases of single infections (23.9\%). The most frequent co-infections were observed by H. nana and H. diminuta (16.4\%).
\end{abstract}

Key words: helminth parasites, Black rat

\section{INTRODUCTION}

Rattus rattus (Rodentia: Muridae), also known as the black rat, is one of the most common harmful rodents in both hemispheres of the planet. As a typical omnivorous mammal, it often lives near inhabited buildings, around landfills and sewers. An increasing density of rat and mouse populations is due to their high reproduction ability, rapid adaptability to changing environmental conditions and the opportunity to select resistance to some rodenticide substances (1). It has been confirmed that these harmful rodents play an important role as a reservoir of many pathogenic agents transmissible to humans and pose a serious threat to the public health. (2). Rat helminth fauna includes a variety

Corresponding author: Assist. Prof. Petar Iliev, $\mathrm{PhD}$

E-mail address: petyo_todorow@abv.bg

Present address: Department of Veterinary Microbiology, Infectious and

Parasitic Diseases, Faculty of Veterinary Medicine, Trakia University, 6000

Stara Zagora, Bulgaria

Phone: +38942699 587

Copyright: $\odot 2017$ Iliev P.T. This is an open-access article published under the terms of the Creative Commons Attribution License which permits unrestricted use, distribution, and reproduction in any medium, provided the original author and source are credited.

Competing Interests: The authors have declared that no competing interests exist.

Available Online First: 2 July 2017

Published on: 15 October 2017

https://doi.org/10.1515/macvetrev-2017-0021 of species such as cestodes Hymenolepis diminuta, Hymenolepis nana, Taenia taeniaeformis larval stage (Strobilocercus fasciolaris) and nematodes Trichuris muris, Syphacia spp., Capillaria hepatica and Aspiculuris tetraptera (2-7). Infection by $A$. tetraptera, Hymenolepis spp. and Oxyuridae spp. in rats and mice in Bulgaria has been reported (8). The rodents also play an important role as an intermediate host and a source of Echinococcus multilocularis infection for carnivorous (9) and as a reservoir of Trichinella spiralis for pigs and humans (10).

Generally, the synantropic rodents are an important factor in human parasitic diseases. Due to the lack of updated information on the problem our aim was to investigate the helminth fauna of the black rat in some regions of Stara Zagora district.

\section{MATERIAL AND METHODS}

The study was carried out in four rabbit farms and a zoo near Stara Zagora. It included examining carcasses of 67 black rats collected after a scheduled exterminating by placing the poisoned bait chunks containing $0.005 \%$ bromadiolone. Deratisation in 
the studied sites usually takes place several times a year depending on the density of rodent population.

Rat identification was achieved by measuring the significant somatometric and craniometric parameters described by Peshev et al. (11). After necropsy, the gastro-intestinal tracts and all organs within the abdominal and thoracic cavities were inspected for presence of adult helminths or larvae. The intestinal content was examined by standard salt flotation and sedimentation techniques for detection of parasite eggs. Liver smears were prepared to observe the eggs of $C$. hepatica. Pieces of diaphragm and masseters were examined by compression method to detect muscle Trichinella larvae. Adult worms and eggs were identified by using the descriptions of Baker (12).

\section{RESULTS}

Single and mixed infections by up to three helminths were found in $53(79.1 \%)$ of all the examined rats. Eight species were identified: four belonging to Class Cestoda ( $H$. diminuta, H. nana, T. taeniaeformis larvae, T. polyacantha larvae), two to Class Secernentea (S. obvelata, A. tetraptera) and two to Class Adenophorea (C. hepatica, T. muris).

Table 1. Frequency of helminths in black rats $(n=67)$

\begin{tabular}{lll}
\hline Helminth species & $\begin{array}{l}\text { Prevalence } \\
(\mathbf{\%})\end{array}$ & $\begin{array}{l}\text { Confidence intervals } \\
(\mathbf{9 5 \% )}\end{array}$ \\
\hline Hymenolepis nana & 43.3 & $31.4-55.1$ \\
Hymenolepis diminuta & 47.8 & $35.8-59.7$ \\
Capillaria hepatica & 9.0 & $2.1-15.8$ \\
Taenia taeniaeformis larvae & 7.5 & $1.2-13.8$ \\
Syphacia obvelata & 4.5 & $0-9.4$ \\
Aspiculuris tetraptera & 3.0 & $0-7.1$ \\
Trichuris muris & 3.0 & $0-7.1$ \\
Taenia polyacantha larvae & 1.5 & $0-4.4$ \\
\hline
\end{tabular}

Table 2. Frequency of single and mixed infection in black rats $(n=67)$

\begin{tabular}{lll}
\hline & Prevalence & Confidence \\
& $\mathbf{( \% )}$ & intervals (95\%) \\
\hline Hymenolepis nana & 14.9 & $6.4-23.5$ \\
Hymenolepis diminuta & 23.9 & $13.7-34.1$ \\
Syphacia obvelata & 1.5 & $0-4.4$ \\
Hymenolepis nana + Hymenolepis diminuta & 16.4 & $7.5-25.3$ \\
Hymenolepis nana + Syphacia obvelata & 4.5 & $0-9.4$ \\
Hymenolepis nana + Capillaria hepatica & 3.0 & $0-7.1$ \\
Hymenolepis diminuta + Taenia taeniaeformis larvae & 3.0 & $0-7.1$ \\
Taenia taeniaeformis larvae + Capillaria hepatica & 3.0 & $0-7.1$ \\
Hymenolepis nana + Aspiculuris tetraptera & 1.5 & $0-4.4$ \\
Hymenolepis diminuta + Trichuris muris & 1.5 & $0-4.4$ \\
Hymenolepis diminuta + Hymenolepis nana + Aspiculuris tetraptera & 1.5 & $0-4.4$ \\
Hymenolepis nana + Capillaria hepatica + Trichuris muris & 1.5 & $0-4.4$ \\
Hymenolepis diminuta + Capillaria hepatica + Taenia taeniaeformis larvae & 1.5 & $0-4.4$ \\
Hymenolepis diminuta + Taenia taeniaeformis larvae + Taenia polyacantha larvae & 1.5 & $0-4.4$ \\
\hline
\end{tabular}


Out of all the investigated rats, 27 (40.3\%) were infected by one helminth species and 26 $(38.8 \%)$ by more than one. Mixed infections with two and three helminths were found in $32.8 \%$ and $6.0 \%$, respectively. Hymenolepis diminuta was a predominant species in cases of single infections (23.9\%). Hymenolepis nana was the main agent in mixed infections (28.4\%). The most frequent coinfection was $H$. nana/ $H$. diminuta (16.4\%).

No trematodes and acanthocephalans were discovered. Muscle Trichinella larvae and cysts of $E$. multilocularis were also not detected. All additional results are presented in Tables 1 and 2. Detected eggs, adult helminths and larvae are shown in Fig. 1,2 and 3.

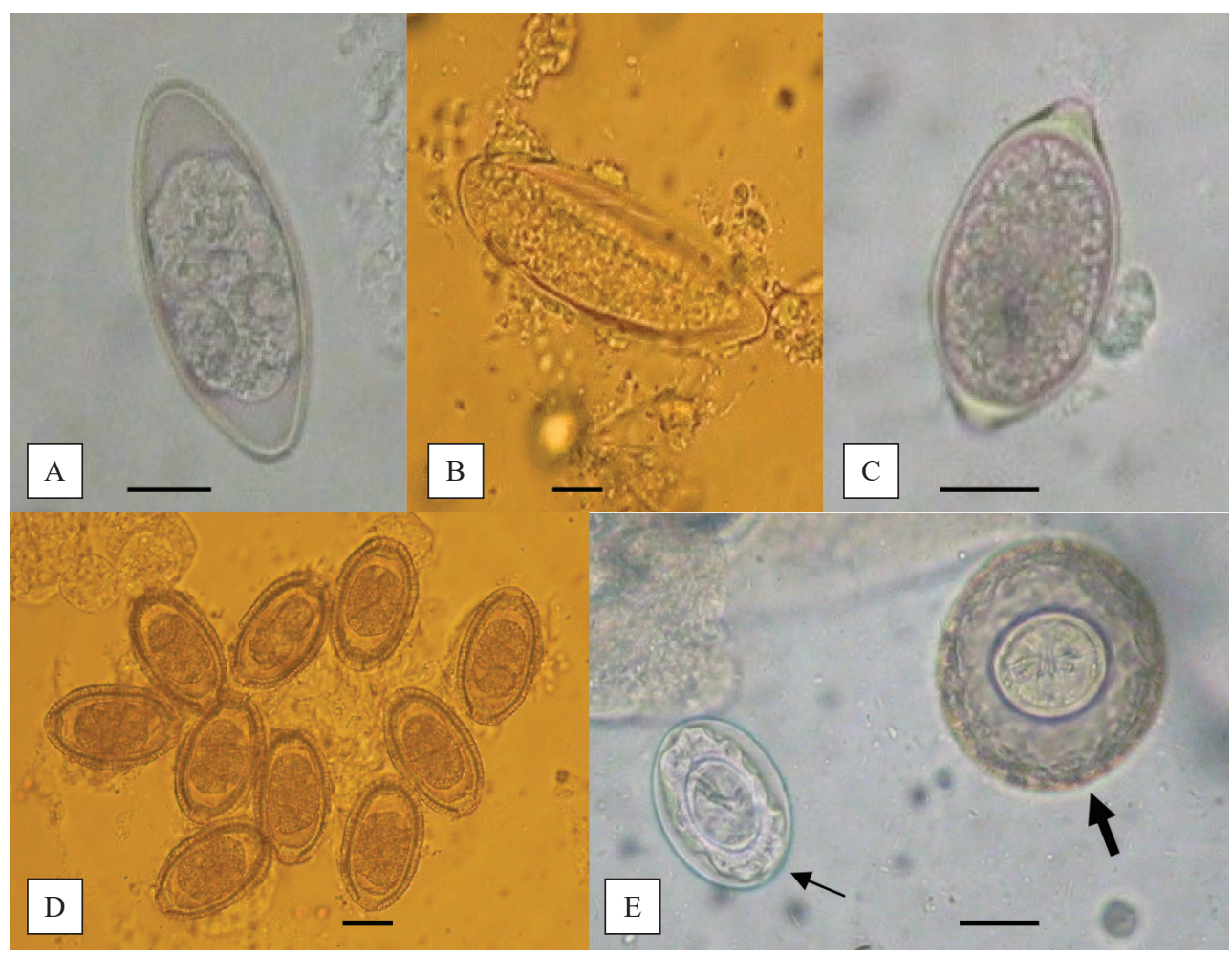

Figure 1. Eggs of A. tetraptera (A), S. obvelata (B), T. muris (C), C. hepatica (D), H. diminuta (thick arrow) and H. nana (thin arrow) (E) (magnification bar $20 \mu \mathrm{m}$ )

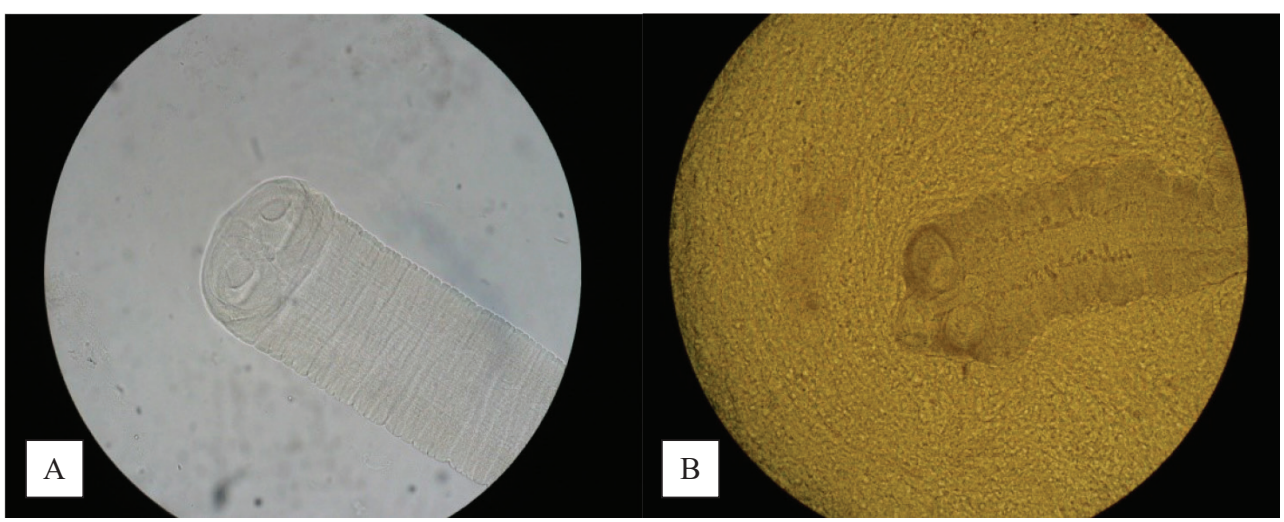

Figure 2. Scolices of H. diminuta (A) and H. nana (B) (40X) 


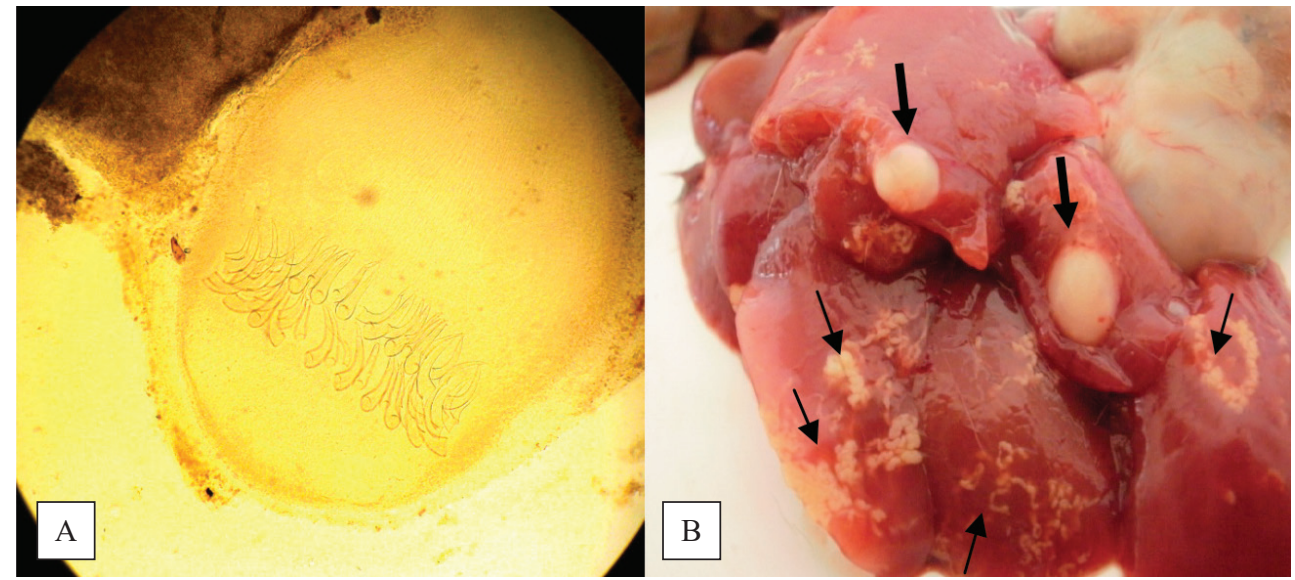

Figure 3. Metacestode of T. polyacantha (A) (40X), T. taeniaeformis larvae (thick arrows) and $C$. hepatica migration routes (thin arrows) (B)

\section{DISCUSSION}

Reports from Serbia (1) and Croatia (7) showed prevalence of hymenolepidids among rodents in $30.5 \%$ and $36.9 \%$ of cases, respectively, which fully corresponds to our data. In contrast, those infections in humans are rare. According to Genov (13) the incidence of $H$. diminuta infection in humans is sporadic and varies between $0.001 \%$ to $5.5 \%$ of the human population (14).

In the present study we found high prevalence of $H$. nana infection which is in agreement with the data presented by Gilioli et al. (15). The authors detected $H$. nana in $53.3 \%$ of examined rats. The possibility of direct $H$. nana transmission between humans and rodents without the presence of an intermediate host (16) and autoinfection possibility $(17,18)$ explains the high prevalence of this cestode in humans compared to $H$. diminuta infection (16). In addition, $H$. nana is found mostly in countries with tropical and subtropical climates and affects about 21 million people (19). In Bulgaria as a country with a typical temperate climate, Genov (13) reported H. nana infection in $0.9 \%$ of the human population. A new data presented by Kurdova et al. (20) revealed 116 cases $(0.023 \%)$ in 2010.

Our results showed a low prevalence of C. hepatica. Liver smears revealed migration routes filled with eggs of Capillaria in $9.0 \%$ of rats, which is not in accordance with some reports $(21,22,23)$. The authors reported the prevalence of hepatic capillariasis between $23 \%$ and $75 \%$, but in brown rat (Rattus norvegicus). In contrast, hepatic capillariasis is a rare condition in humans (24). The transmission of $C$. hepatica among animals and humans occurs by ingestion of embryonated eggs which are released into the environment after the host death (25). In the surveyed buildings included in this study, extermination with apparent effect is regularly done, followed by collection and destruction of dead rodents. This approach has proven very effective against the distribution of both capillariasis and echinococcosis due to E. multilocularis. Such is the case with feline T. taeniaeformis. Its larvae develop in murid rodents which suggests a high prevalence among rats and mice, generally. In our investigation, the access of stray cats into animal buildings is limited. Larvae of T. taeniaeformis among population of $R$. rattus was found to vary between $3.5 \%$ and $4.34 \%$ $(26,27)$.

A lower infection rate by pinworms (A. tetraptera and $S$. obvelata), whipworm (T. muris) and larvae of $T$. polyacantha was recorded in this study. Our results also showed almost equal number of rats with a single $(\mathrm{n}=27)$ and mixed infection $(\mathrm{n}=26)$. The combination between $H$. nana and $H$. diminuta was the most common. In Bulgaria, Tsankova et al. (28) investigated helminth fauna of black rat living in food industry enterprises. The authors revealed S. obvelata, H. nana and H. diminuta.

\section{CONCLUSION}

The presence of the black rat around animal facilities poses a high risks not only for animals, but also for farm teams. Results of our study showed that more than half of examinated rats (79.1\%) were infected with one $(40.3 \%)$ or more 
helminths (38.8\%). Hymenolepis diminuta and Hymenolepis nana were the most prevalent species in parasitocenosis. Moreover, the humans are able to be infected by $H$. nana. Based on these findings, we believe that it is necessary to perform a systematic control aimed at full rat eradication in order to prevent zooanthroponoses.

\section{CONFLICT OF INTEREST STATEMENT}

The authors declared that they have no potential conflict of interest with respect to the authorship and/or publication of this article.

\section{ACKNOWLEDGEMENT}

The authors would like to thank the manager of the Zoo in Stara Zagora as well as the owners of rabbit farms for provided assistance. We also appreciate the help from Laboratory of Helminthology at Trakia University, Bulgaria.

\section{REFERENCES}

1. Kataranovski, D., Kataranovski, M., Deljanin, I. (2010). Helminth fauna of Rattus norvegicus Berkenhout, 1769 from the Belgrade area, Serbia. Arch Biol Sci Belgrade. 62 (4): 1091-1099.

https://doi.org/10.2298/ABS1004091K

2. Claveria, F.G., Causapin, J., Guzman, M.A., Toledo, M.G., Salibay, C. (2005). Parasite biodiversity in Rattus spp. caught in wet markets. Southeast Asian J Trop Med Public Health. 36 (4): 146-148. PMid:16438200

3. Davoust, B., Boni, M., Branquet, D., Lahitte, J., Martet, G. (1997). Research on three parasitic infestations in rats captured in Marseille: evaluation of the zoonotic risk. Bull Acad Natl Med. 181 (5): 887-895.

PMid:9312363

4. Mafiana, C.F., Osho, M., Sam-Wobo, S. (1997). Gastrointestinal helminth parasites of the black rat (Rattus rattus) in Abeokuta, Southwest Nigeria. J Helminthol. 71 (3): 217-220.

https://doi.org/10.1017/S0022149X00015947 PMid:9705679

5. Milazzo, C., Cagnin, M., Dibella, C., Geraci, F., Ribas, A. (2010). Helminth fauna of commensal rodents, Mus musculus (Linnaeus, 1758) and Rattus rattus (Linaeus, 1958) (Rodentia- Muridae) in Sicili (Italy). Rev Ibero-Latinoam Parasitol. 69 (2): 194-198.
6. Rafique, A., Rana, A., Khan, H.A., Sohail, A. (2009). Prevalence of some helminths in rodents captured from different city structures including poultry farms and human population of Faisalabad, Pakistan. Pak Vet J. 29 (3): 141-144.

7. Stojcevic, D., Mihljevic, Z., Marnculic, A. (2004). Parasitological survey of rats in rural regions of Croatia. Vet Med - Czech. 49 (3): 70-74.

8. Kesyakova, S., Zhelev, G., Dimitrova, A., Bonovska, M., Sabev, P., Lalkovska, T., Zhelyazkov, P. (2015). Microbiological and parasitological investigations in rodents posing sanitary risk in animal facilities. Bulg J Vet Med. 18 (2): 167-172. https://doi.org/10.15547/bjvm.821

9. Borgsteede, F., Tibben, J., Giessen, J. (2003). The musk rat (Ondatra zibethicus) as intermediate host of cestodes in the Netherlands. Vet Parasitol. 117 (1-2): 29-36.

https://doi.org/10.1016/j.vetpar.2003.07.015 PMid:14597276

10. Onyenwe, I., Ihedioha, J., Ezeme, R. (2009). Prevalence of zoonotic helminths in local house rats (Rattus rattus) in Nsukka, Eastern Nigeria. Anim Res Int. 6 (3): 1040-1044.

11. Peshev, C., Nankinov, D., Peshev, D. (2003). Vertebrates in Bulgaria (pp. 324-384). Sofia: Bulvest 2000 Press.

12. Baker, D. (2007). Flynn's parasites of laboratory animals (pp. 330-348). Blackwell Publishing. https://doi.org/10.1002/9780470344552

13. Genov, T. (1998). Practical parasitology (pp. $220-$ 268). Sofia: Znanie Press.

14. Patamia, I., Cappello, E., Castellano-Chiodo, D., Greco, F., Nigro, L., Cacopardo, B. (2010). A human case of Hymenolepis diminuta in a child from Eastern Sicily. Korean J Parasitol. 48 (2): 167-169. https://doi.org/10.3347/kjp.2010.48.2.167 PMid:20585535 PMCid:PMC2892574

15. Gilioli, R., Andrade, L., Passos, L., Silva, F., Rodrigues, D., Guaraldo, A. (2000). Parasite survey in mouse and rat colonies of Brazilian laboratory animal houses kept under differents sanitary barrier conditions. Braz J Vet Res An Sci. 52 (1): 33-37. https://doi.org/10.1590/s0102-09352000000100009

16. Marangi, M., Zechini, B., Fileti, A., Quaranta, G., Aceti, A. (2003). Hymenolepis diminuta infection in a child living in the urban area of Rome, Italy. J Clin Microbiol. 41 (8): 3994-3995.

https://doi.org/10.1128/JCM.41.8.3994-3995.2003 PMid:12904439 PMCid:PMC179784 
17. Dvorak, J., Jones, A., Kuhlman, J. (1961). Studies on the biology of Hymenolepis microstoma (Djardin, 1845). J Parasitol. 47 (5): 833-838.

https://doi.org/10.2307/3275481

PMid:13888781

18. Katiyar, J., Gupta, S., Sen, A. (1983). Susceptibility, chemotherapeutic reaction and immunological response of rat and mouse to Hymenolepis nana - a comparative study. Indian J Exp Biol. 21 (7): 371-374. PMid:6667992

19. Parija, S. (1990). Review of parasitic zoonoses (pp. 268280). Delhi: AITBS Publishers Distributers.

20. Kurdova, R., Raynova, I., Yordanova, D., Harizanov, R., Marinova, I., Bikov, I., Kaftandjiev, I., Tsvetkova, N. (2011). Characteristic of parasitic disease in Bulgaria in 2010. Information J. NCIPD. 5, 5-31.

21. Ceruti, R., Sonzogni, O., Origgi, F., Vezzoli, F., Cammarata, S., Guisti, A., Scanziani, E. (2001). Capillaria hepatica infection in wild brown rats (Rattus norvegicus) from the urban area of Milan, Italy. J Vet Med. B Infect Dis Vet Public Health. 48 (3): 235-240.

https://doi.org/10.1046/j.1439-0450.2001.00436.x PMid:11393820

22. Farhang-Azad, A. (1977). Ecology of Capillaria hepatica (Bancroft, 1893) (Nematoda). Dynamics of infection among Norway rat populations of the Baltimore Zoo, Baltimore, Maryland. J Parasitol. 63 (1): 117-122.

https://doi.org/10.2307/3280114

PMid:845721
23. Webster, J., McDonald, D. (1995). Parasites of wild brown rats (Rattus norvegicus) on UK farms. Parasitology 111 (3): 247-255.

https://doi.org/10.1017/S0031182000081804 PMid:7567093

24. Stojcevic, D., Marinculic, A., Mihaljevic, Z. (2002). Prevalence of Capillaria hepatica in Norway rats (Rattus norvegicus) in Croatia. Vet Arhiv. 72 (3): 141-149.

25. Siti-Shafiyyah, C., Jamaiah, I., Rohela, M., Lau, Y., Siti-Aminah, F. (2012). Prevalence of intestinal and blood parasites among wild rats in Kuala Lumpur, Malaysia. Trop Biomed. 29 (4): 544-550. PMid:23202599

26. Pakdel, N., Naem, S., Rezaei, F., Chalehchaleh, A. (2013). A survey on helminthic infection in mice (Mus musculus) and rats (Rattus norvegicus and Rattus rattus) in Kermanshah, Iran. Vet Res Forum. 4 (2): 105-109.

PMid:25653780 PMCid:PMC4313010

27. Rodriguez-Vivas, R., Panti-May, J., Parada-Lopez, J., Hernandez-Betancourt, S., Ruiz-Pina, H. (2011). The occurrence of the larval cestode Cysticercus fasciolaris in rodent populations from the Cuxtal ecological reserve, Yucatan, Mexico. J Helminthol. 85 (4): 458-461. https://doi.org/10.1017/S0022149X10000817 PMid:21208511

28. Tsankova, Z., Vuchev, D. (2008). Synantropic rodents - a source of zooanthroponoses and planning of prophylaxis actions. DDD Bulletin 25-27. 